\title{
Students' Perceptions toward Bilingual Education at ICP Chemistry Education in Makassar
}

Sucitra

Sucitra964@gmail.com

English Education Department, Post Graduate Program, State University of Makassar, Indonesia Received: August 3, 2020

Received in Revised: August 11, 2020

Accepted: August 13, 2020

\section{Abstract}

This study aims to find out: (1) students' perceptions toward bilingual education in ICP (International Class Program) toward the use of two languages of instructions (English and Indonesian) by the lecturer in classroom. (2) to investigate its benefit for students in ICP chemistry education. The researcher adopted a descriptive qualitative research with a case study method. To gain the data, the researcher employed questionnaire with the students. the subjects in this study were 24 of students sixth semester belong to the International Class Program (ICP) chemistry education in State University of Makassar. The results of this study showed that there were the bilingual education helps the students to gain control their English skill. It showed that students' positive perceptions toward the use of bilingual language as language instruction in the classroom by the lecturer. It is concluded that teaching chemistry in English facilitates the learners' attempt in learning English.

Keywods: Students' Perceptions, Bilingual Education, International Class Program (ICP).

\section{Introduction}

In Indonesia, bilingual education has recently been a trend to find schools with bilingual program, meaning that it is applying the use of two languages in teaching a subject content. Santoso (2015) states from data of four other experts that there is a tendency the bilingual program students obtained better achievements than those in monolingual program. In the context of the Indonesian multilingual society, where English is taught as a foreign language (EFL), such bilingual program has become a significant breakthrough, encouraging the use of English in non-English subjects (known as subjects across curriculum).

Bilingual education has become a prestige for a number of educational institutions in Indonesia. There are many schools that use a bilingual system in teaching and learning activities. The government, specifically the Department of National Education, has launched a program called "bilingual program" in which several subjects (Math, Chemistry, Biology, and Physics) are taught in English. The objectives of this program are to produce graduates whose command of English in high and to produce graduates who have high competence in several subjects in accordance with the development of those subjects. There are still problems about the implementation of bilingual instruction programs which need to think it over. Among these are still limited English language skills of bilingual Chemistry teachers. Besides, in fact, thus far there is not yet an appropriate model of teaching bilingual to the students' conditions. Consequently, the use of these two languages, Indonesian and English, often makes wrong concept to the materials which have been being studied, and the aims of bilingual program are 
not achieved well, that is to increase the students' ability in the material mastery, and their English prosperity.

The application of bilingual classes is not simple as possible. There are many things that need to be considered in conducting it, such as students' linguistic skills, teachers' competence and models applied in teaching and learning activities. Karahan (2005) also stated that teaching foreign languages, particularly English, has always been supported in order to be effective in the international arena, to gain knowledge about national and global value and to make comments on them, The point is that bilingual education is one possible solution for educating minority students. Although some students succeed without such intervention, others require the structure it provide.

In accordance with the explanation above, the writer was eager to conduct this case study about the bilingual education at International Class Program (ICP) chemistry education in State University of Makassar. It is aimed to investigate the tendency of bilingual education which is applied by the institutions, It would like to investigate the perceptions of students toward bilingual education at International Class Program (ICP).

\section{Literature Review}

\section{Theories of Perception}

Yolanda Williams (2016) explained that perception can be defined as our way to recognize and interpret information. We have gathered through our senses. This also includes how we respond to a certain situation with the given information. Moreover AlleyDog (2016) stated that we use our senses to detect and recognize something which then allows us to process the information and discover the emotions and react to the situation we see, which is perception.

There are many theories about different subjects in perception. There are also disorders that relate to perception even though I thought that perception is just a person's view point. Perception is often influenced or even biased by our expectations, experiences, and moods. This is where the mind comes in, not just the brain. We are even able to fool ourselves due to our expectations. Our eyes play a role in perceiving information to our brain, but really, our mind has the most power. Our perceptual set is the psychological factors. While our mind is responsible for most of the ways we perceive things.

\section{Bilingual Education}

Bilingual education is a program intended to the students in which English is not their native language. It is aimed to increase the students' English proficiency. Brisk (2006) stated that bilingual education is viewed as qualified education delivered in two languages. It means that the process of teaching and learning at class should be in the form of two languages in delivering the materials.

The definition of bilingual education is various in different definitions. For instance, bilingual education was viewed as quality education delivered in two languages. Lee (2008: 85) stated that this tiered bilingual class is called as bilingual transitional education because students are not directly taught in the English language in full, but gradually, the portion of the English language grows larger and the portion of students' language increasingly small. The portion could be defined or categorized in accordance with the type of bilinguals. From those explanations it can be simply drawn an inference that bilingual education program is a model of teaching instruction 
which implements two languages as media of communicating or instructing in the teaching and learning process in bilingual classes.

\section{International Class Program (ICP)}

The curriculum is one component that has a strategic role in the education system. Curriculum on International Class Program UNM Faculty of Science, has studied the course material to the students as prospective educators to consider the needs of field-oriented learners. The International Class Program (ICP) is a class that not only uses the national curriculum, but also uses the Cambridge curriculum. It referred to Cambridge International Curriculum that:

Cambridge programmes combine an emphasis on mastering subjects in depth with the development skills for study and work in the future. We value deep subject knowledge as well as the conceptual understanding that helps students make links between different aspects of a subject. These are transferable skills that will last a lifetime, preparing students for their future lives. They also make learning enjoyable and rewarding.

\section{Methods}

In order to explore and to know the students' perception toward bilingual education at International Class Program (ICP) chemistry education in State University of Makassar. This study adopted a qualitative descriptive research with case study method which deals with the data collection, analysis, and interpretation of narrative in order to gain insight into a particular phenomenon of interest (Gay, Mills, \& Airasian, 2012).

\section{Participants}

The participants of this research were 24 of students sixth semester belong to the International Class Program (ICP) chemistry education in State University of Makassar. The sample selected by using purposive sampling technique of this research, the researcher only took one class as the sample.

\section{Data Collection Technique}

In attempt to collect the data, this study employed questionnaire with the students by using google forms survey in order to collect the data. A questionnaire was send to the students who belong to selected Chemistry bilingual classroom. The data from questionnaire was aimed to find out the students' perception toward bilingual education at International Class Program and the benefit of bilingual education uses for students in learning English as a language instruction in the classroom.

\section{Data Analysis Technique}

The data gained from questionnaire were analysed and explored on Likert scale (Ockert: 2005) for helping the researcher classify to be counted and classified about students' perception toward bilingual education in learning English as a language instruction in the classroom.

\section{Results and Discussion}

The descriptions of the data in this research are divided into two points. First what were the students' perception toward bilingual education at International Class Program (ICP) chemistry education in State University of Makassar. Second, the benefits of bilingual education use for students in learning English as a language instruction in the classroom. 


\section{Data from Questionnaire}

The findings from the questionnaire were also supported by the data. The statements were mentioned below:

1. The use of bilingual by the lecturer in ICP (International Class Program) chemistry education helps you in learning English.

2. The use of bilingual by the lecturer in ICP (International Class Program) make you understand the material given by the lecturer.

3. The use of bilingual by the lecturer in ICP (International Class Program) makes you easy to understand new vocabularies.

4. The use of bilingual by the lecturer in ICP (International Class Program) chemistry education helps you to be fluent and accurate on your English-Speaking skill.

5. The use of bilingual by the lecturer in ICP (International Class Program) makes you easy in English writing skill.

6. The use of bilingual by the lecturer in ICP (International Class Program) makes you confuse to learn English.

\section{Rating Scale}

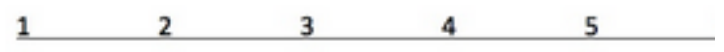
1 = Strongly disagree
$4=$ Agree
2 = Disagree
$5=$ Strongly Agree
3 = Enough

The data were analyzed and explored by using some steps based on Likert scale (Ockert, 2005) for helping the researcher classify and interpret, it easily to be counted and classified whether the students agree or disgree about the lecturer's bilingual language use in the classroom. It is supported by using google forms, It was so helpful to researcher for collecting and analyzing the data. Based on the data gained from some statements in the questionnaire. It showed that students' perceptions to the use of bilingual education by the lecturer were positive, starting that bilingual language was necessary in the classroom. Based on the findings, this study revealed that bilingual materials gave certain advantages for the students learning English. Based on the results of the questionnaires, students stated that there were four benefits of bilingual language instruction used by the lecturers.

- Making them easy to understand what the lecturer explained in the lesson.

- Helping them understand new vocabularies.

- Helping them do exercises.

- Helping them read something in English correctly. 


\section{Results of Students' Questionnaire}

Regarding the first research question which was aimed to investigate students' perceptions toward bilingual education at International Class Program (ICP) chemistry education in State University of Makassar. This study revealed that students showed their positive perceptions of the use of bilingual materials in their classroom. This finding was supported by analysis of the data gained from the questionnaire. Based on the statement, it could be revealed that students had strong positive perceptions about bilingual education in their classroom. It proven by the amount of central tendency of this statement which reached $78 \%$, indicated that they had a very strong perceptions of the use of bilingual education used by lecturer.

In addition, It was also supported in that no students answered strongly disagree to the first until third statements (65\% agreed $35 \%$ strongly agree). It was shown by four statements (number 1 5 ) in the questionnnaire responded by the students. The last statement reached the central tendency at the level of "enough" it was $30 \%$. From the result of statement number six , the researcher concluded that more than a half of the students were strongly agreed that the use of bilingual education by their lecturer did not confuse them in understanding to materials through English instructions. Therefore, the researchers concluded that the students had positive perception toward bilingual education in their class.

\section{Conclusion}

The conclusions of this study reveal that lecturer's bilingual education were implemented at International Class Program (ICP) chemistry education in State University of Makassar to teach an material using English language instruction to the students who are at the non-English proficiency. The implementation of the lecturer's materials was based on a bilingual approach in which the students' mother tongue is combined with the target language being studied. However even the last statement reached the central tendency "enough" level, it was good result. It could be classified as a supporting statement for the first statement, which indicated that students had positive perceptions toward the lecturer's bilingual materials. Furthermore, there are also four benefiits of language instruction used by lecturer to conduct an bilingual class, which make the lesson easy to understand, help students understand new content in vocabulary in English, and help them to ask and learn to do something in English.

\section{References}

Alleydog., Sensation \& Perception. (2016). Class Notes.

Brisk., (2006) Bilingual Education: From Compensatory to Quality Schooling. Second Edition. Lawrence Erlbaum Associates.

Gay, L. R., Mills, G. E., \& Airasian, P.W. (2012). Educational Research: Competencies for Analysis and Applications (10th ed). Boston: Pearson.

Lee, C., (2008). Interdisciplinary collaboration in English language teaching: Some observations from subject teachers' reflections. Reflections on English Language Teaching, (Vol. 7, (2), 129-138).

Ockert, D. (2005). Substantive scale verification: A likert scale analysis and critique of university student pedagogical activity preferences. JALT Hokkaido Journal, 9, 48-64. 
Santoso, D., Ginting , P., (2015). 1st Edition. Bilingual Education Program. Jakarta: Prenadamedia.

Unknown., (2020). Cambridge International Curriculum. www.cambridgeinternational.org 25/03/20.

Williams, Yolanda., (2016). What is perception?. Chapter 3.7 Wlliams' notes. 